\title{
Improved geotechnical properties in salt-treated highly sensitive landslide-prone clays
}

1 Tonje Eide Helle MSc, PhD

Geotechnical engineer, Directorate for Public Roads, Trondheim, Norway (corresponding author: tonje.helle@vegvesen.no) (Orcid:0000-0003-3527-7600)

2 Steinar Nordal MSc, PhD

Professor, Department of Civil and Environmental Engineering, Norwegian University of Science and Technology, Trondheim, Norway
3 Per Aagaard MSC, PhD

Professor Emeritus, Department of Geosciences, University of Oslo, Oslo, Norway
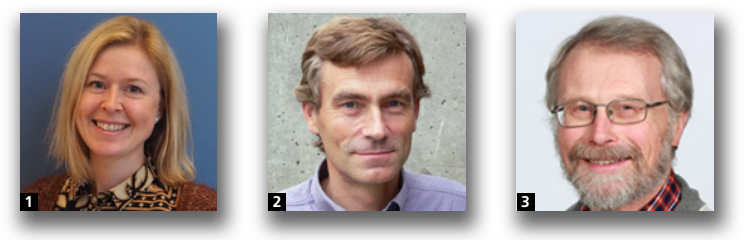

Retrogressive or progressive landslides in slopes with highly sensitive quick clays may extend several hundred metres from where the slide was initiated. Reintroducing high salt contents to the pore water of leached low-saline quick clays may inhibit the development of such large landslides. Wells filled with potassium chloride $(\mathrm{KCl}) \mathrm{were}$ installed in a quick-clay deposit at Dragvoll, Trondheim, Norway, to investigate the impact of changed pore-water chemistry on the geotechnical properties. The clay ceased to be quick due to favourable changed ion composition in the pore water, even at low salt contents, thus inhibiting retrogressive development. The apparent pre-consolidation stress ( $p_{c}^{\prime}$ ) increased with increasing salt contents and the immediate collapse in structure typically seen in quick clays was avoided at loads just beyond $p_{\mathrm{c}}^{\prime}$ by changing the pore-water chemistry. Quick clay treated with $\mathrm{KCl}$ may therefore work as a barrier against retrogressive development and reduce the risk of initiation of progressive landslides.

\section{Notation}

$c_{\mathrm{u}} \quad$ undrained shear strength

$c_{\mathrm{uc}} \quad$ peak undrained shear strength

$c_{\text {ur }} \quad$ remoulded shear strength

$e \quad$ void ratio (-)

$e_{i} \quad$ void ratio at time of deposition (-)

$e_{0} \quad$ initial void ratio at the start of the test

$K_{0}^{\prime} \quad$ coefficient at rest

$M_{\text {OC }} \quad$ oedometer modulus at stresses below $p_{\mathrm{c}}^{\prime}$

$p_{\mathrm{c}}^{\prime} \quad$ apparent pre-consolidation stress

$w \quad$ natural water content

$\gamma \quad$ shear strain

$\gamma_{\mathrm{f}} \quad$ shear strain at failure

$\gamma_{80} \quad$ shear strain at $20 \%$ reduction of $c_{\text {uc }}$ after peak

$\Delta e \quad$ difference in the void ratio from $e_{0}$ to the void ratio at in situ effective overburden stress

$\Delta \gamma_{80} \quad$ brittleness parameter

$\Delta \varepsilon_{\mathrm{KCl}} \quad$ strain during the immediate collapse of the structure at loads beyond $p_{\mathrm{c}}^{\prime}$ in potassium chloride-treated clay

$\Delta \varepsilon_{\mathrm{QC}} \quad$ strain during the immediate collapse of the structure at loads beyond $p_{\mathrm{c}}^{\prime}$ in the original quick clay

$\varepsilon$

$\begin{array}{ll}\rho & \text { bulk density } \\ \sigma^{\prime} & \text { applied effective vertical stress } \\ \sigma_{v}^{\prime} & \text { effective vertical stress } \\ \sigma_{v i}^{\prime} & \text { effective overburden stress at time of deposition } \\ \sigma_{v p}^{\prime} & \text { apparent pre-consolidation stress } \\ \sigma_{\mathrm{v} 0}^{\prime} & \text { effective overburden stress } \\ \sigma_{3}^{\prime} & \text { effective horizontal stress } \\ \psi_{0} & \text { electric surface potential } \\ 1 / \mathrm{K} & \text { thickness of the diffuse double layer }\end{array}$

\section{Introduction}

The geotechnical properties of post-glacial marine clays are greatly influenced by their depositional environment and postdepositional conditions, including weathering and leaching. The forces acting between the clay particles are determined by the stress history and the pore-water chemistry and mineralogy (Mitchell and Soga, 2005; Rosenqvist, 1955; Torrance, 1983). The concentration and composition of ions in the pore fluid have a significant impact on the geotechnical properties, as clays are electrochemically very active (van Olphen, 1963). It is thus essential to understand the impact of clay-water systems on the behaviour of clays when using chemical additions as ground improvement in highly sensitive clays. 
Most clays on the mainland of Norway were deposited in seawater during deglaciation. The clay particles flocculated and entrapped highly saline water with salt contents of $30-35 \mathrm{~g} / 1$ in their large voids. The structure of clays with high salt contents is stable as the repulsive forces are small due to the suppressed diffuse double layer (DDL) surrounding the clay minerals. Isostatic uplift has exposed these clays to meteoric groundwater flow, diluting the salt content in their pore water (Rosenqvist, 1946, 1977). A decreasing salt content increases the thickness of the DDL around the clay minerals (Figure 1(a)), increasing the repulsive forces between the clay particles. Thus, the structure may collapse during loading and the clays may behave as a liquid when remoulded. Highly sensitive, leached marine clays, termed quick clays, are defined by a remoulded shear strength $\left(c_{\mathrm{ur}}\right)$ of less than $0.5 \mathrm{kPa}$ (NGF, 2011). Quick clays often have liquid limits less than their natural water content, a liquidity index (LI) larger than $1 \cdot 2$ (Leroueil et al., 1983) and salt contents of less than $2 \mathrm{~g} / 1$ (Rosenqvist, 1977; Torrance, 1979). As quick clays become liquid when remoulded, these clays pose a serious risk for catastrophic landslides in inhabited areas, especially in midNorway and the southeast part of Norway. Reintroducing high salt contents to these highly sensitive, leached marine clays reduce the repulsive forces to such an extent that they no longer appear as quick (Bjerrum, 1955; Eggestad and Sem, 1976; Løken, 1968, 1970; Moum et al., 1968; Quigley, 1980; Rosenqvist, 1946, 1953, 1955; Torrance, 1983). Therefore, introducing salt to a clay-water system may reduce the risk of large quick-clay landslides.

Laboratory studies adding various types of salts to quick clays showed that potassium chloride $(\mathrm{KCl})$ had a greater impact on the remoulded shear strength and Atterberg limits than other salts at the same normality (Løken, 1968, 1970; Moum et al., 1968). Therefore, salt wells filled with $\mathrm{KCl}$ were installed in a quick-clay deposit at Ulvensplitten, Oslo, Norway in 1972. This successfully improved the geotechnical properties prior to excavation 18-21 months later (Eggestad and Sem, 1976). Ground investigations carried out 40 years after installation revealed that the salt-treated clay maintained its non-quick behaviour (Helle et al., 2016). Despite the encouraging results from 1972, the salt-well method is not currently used for ground improvement due to limited experience and documentation on the effect of the method. The amount of time required to reach the desired improvement is also an issue and the increase in peak strength is limited compared with other
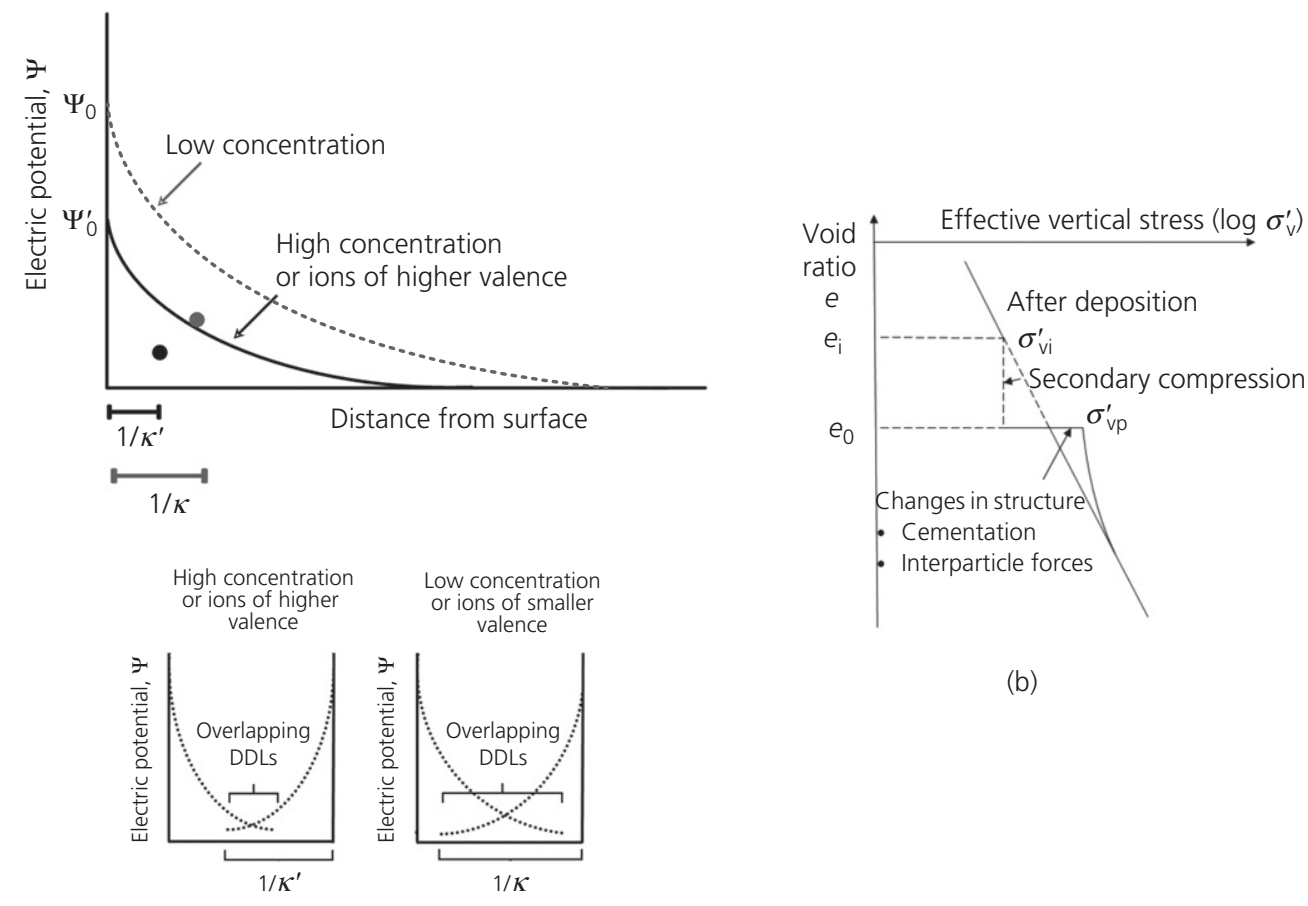

(b)

(a)

Figure 1. (a) Decay of electric potential with distance from the mineral surface. The surface potential $\left(\Psi_{0}\right)$ is higher at low electrolyte concentrations (dotted curve) than at high concentrations $\left(\Psi_{0}^{\prime}\right)$ (full curve). Of two electrolytes of same concentration, the surface potential is lower for the electrolyte consisting of ions of higher valence. Thus, the thickness of the DDL is smaller (1/א). The overlap of the DDLs determines the repulsion between the clay particles (adapted from van Olphen (1963) and Moore and Reynolds (1997)). (b) Effective vertical stress $\left(\sigma_{\mathrm{vi}}^{\prime}\right)$ and void ratio $\left(e_{\mathrm{i}}\right)$ after deposition of the clay. Secondary compression decreases the void ratio $\left(e_{0}\right)$. With time, and without any excess loading or changes in the void ratio, changes in the structure may result in a further apparent increase of the vertical pre-consolidation stress $\left(\sigma_{\mathrm{vP}}^{\prime}\right)$ (modified from Leroueil and Vaughan $(1990)$ ). 
methods used to stabilise sensitive clays, such as lime-cement piling.

In order to investigate the potential of using $\mathrm{KCl}$ for landslide mitigation in quick-clay areas, wells filled with $\mathrm{KCl}$ were installed in a quick-clay deposit at Dragvoll, Trondheim, Norway in January 2013. This in situ experiment at Dragvoll has provided unique documentation of improved geotechnical properties caused by the changed pore-water chemistry. Previous studies carried out in the laboratory, as well as the in situ experiment at Ulvensplitten, have mainly focused on properties in the remoulded state ( $c_{\mathrm{ur}}$ and Atterberg limits (postfailure properties)). Some laboratory studies have also been carried out to investigate the impact of both removing and adding salt on the compressibility of clays. All the studies have shown that the apparent pre-consolidation stress $\left(p_{\mathrm{c}}^{\prime}\right)$ increases and the volume change at increasing loads decreases (decreased compressibility) with increasing salt content (e.g. Bjerrum, 1967; Bryntesen, 2014; Gjengedal, 2012; Helle et al., 2015; Kenney et al., 1967; Torrance, 1974). Quick clays show very brittle behaviour with significantly reduced post-peak strength due to the rapid collapse of the structure. Decreasing this brittleness may prevent large quick-clay landslides. To the authors' knowledge, no studies on in situ $\mathrm{KCl}$ improvement of the pre-consolidation stress, compressibility and brittleness in quick clays have been carried out in the past. The improved geotechnical properties correlated to pore-water chemistry and their effect on reducing the risk of retrogressive and progressive quick-clay landslides (Figure 2) are presented and discussed in this paper.

In order to discuss the results, it is necessary to look back at the geochemical history of quick clays. The pore-water chemistry in post-glacial Norwegian marine clays is affected by the ion composition in the seawater at the time of deposition $\left(\mathrm{Na}^{+}, \mathrm{K}^{+}, \mathrm{Mg}^{2+}\right.$ and $\left.\mathrm{Ca}^{2+}\right)$, microfossils such as shells $\left(\mathrm{Ca}^{2+}\right)$ and weathering of minerals such as chlorite $\left(\mathrm{Mg}^{2+}, \mathrm{Al}^{3+}, \mathrm{Fe}^{2+}\right.$ and $\left.\mathrm{Fe}^{3+}\right)$, feldspar $\left(\mathrm{K}^{+}, \mathrm{Al}^{3+}\right)$ and mica $\left(\mathrm{K}^{+}\right)$. The plasticity index (PI) and $c_{\text {ur }}$ increase with cations at the same normality (equivalents $/ \mathrm{l}=\mathrm{mol} \cdot$ valence of ion $/ \mathrm{l}$ ) in the following order: $\mathrm{Na}^{+}<\mathrm{Ca}^{2+}<\mathrm{Mg}^{2+}<\mathrm{Al}^{3+}<\mathrm{Fe}^{2+}$ and $\mathrm{Fe}^{3+}<\mathrm{K}^{+}$(Bjerrum, 1967). The cations in the pore water and adsorbed positions in clays accumulated in seawater are dominated by sodium $\left(\mathrm{Na}^{+}\right)$ (Mitchell and Soga, 2005; Moum et al., 1971; Penner, 1965; Torrance, 1979). Leaching by meteoric groundwater flow dilutes the salt content in the pore water and introduces cations of higher exchange power and with a stronger effect on suppressing the DDL (Figure 1(a)) to the clay-water system, such as calcium $\left(\mathrm{Ca}^{2+}\right)$ and magnesium $\left(\mathrm{Mg}^{2+}\right)$. Thus, the clay mineral surfaces release $\mathrm{Na}^{+}$into the pore water, replacing them by ions of higher exchange power (higher valence, smaller hydrated radius). Therefore, $\mathrm{Na}^{+}$cations are still, after significant leaching, the abundant cations in the pore water in quick clays (Moum et al., 1971). As long as more than $80 \%$ of the normality of cations in the pore water consists of $\mathrm{Na}^{+}$, the

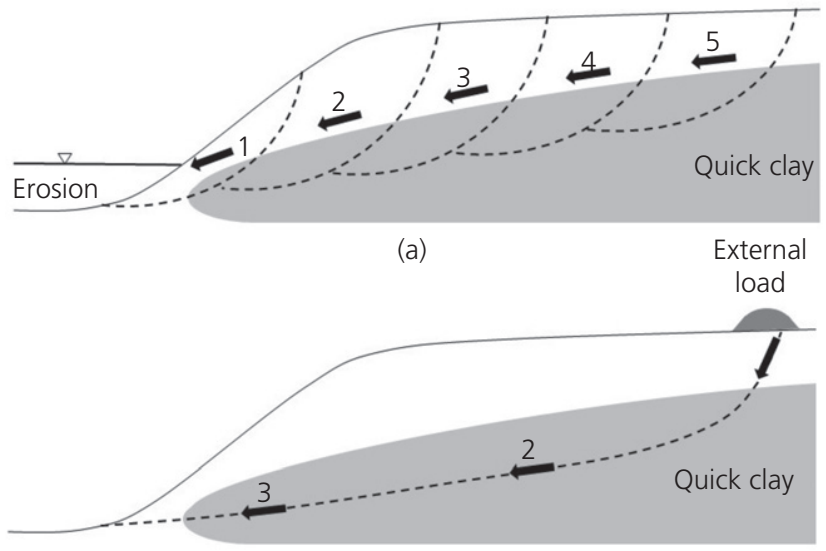

(b)

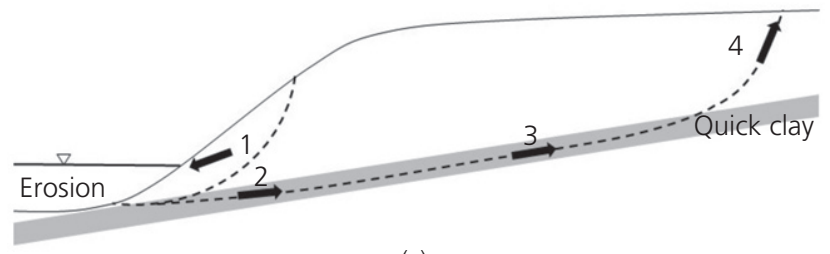

(c)

Figure 2. (a) Retrogressive quick-clay landslide with successive back-scarp failures. (b) Forward progressive quick-clay landslide due to external loading. (c) Backward progressive development along a thin quick-clay layer

clay remains quick. As already mentioned, adding $\mathrm{KCl}$ to quick clays has a beneficial effect on their geotechnical properties. Even though $\mathrm{K}^{+}$is of same valence as $\mathrm{Na}^{+}$, it has a smaller ionic potential and therefore a smaller hydrated radius. Thus, it has a more 'effective' charge and greater ability to suppress the DDL. This explains why $\mathrm{K}^{+}$is a more effective agent for improving post-failure properties than the other major cations $\left(\mathrm{Na}^{+}, \mathrm{Mg}^{2+}\right.$ and $\left.\mathrm{Ca}^{2+}\right)$ at the same normality (Løken, 1968, 1970; Moum et al., 1968). In the studies at Ulvensplitten and Dragvoll, the clays ceased to be quick, obtaining $c_{\text {ur }}>1 \mathrm{kPa}$, when the sum of the normalities of $\mathrm{K}^{+}, \mathrm{Mg}^{2+}$ and $\mathrm{Ca}^{2+}$ over the sum of major cations $\left(\mathrm{Na}^{+}+\mathrm{K}^{+}+\mathrm{Mg}^{2+}+\mathrm{Ca}^{2+}\right)$ exceeded 20\% (Helle et al., 2017a); in the following this is referred to as the $\mathrm{KMgCa}$ ratio. $\mathrm{As} \mathrm{Na}^{+}$is washed out of the system as a result of introducing high concentrations of $\mathrm{K}^{+}$, and leaching groundwater introduces $\mathrm{Ca}^{2+}$ and $\mathrm{Mg}^{2+}$ to the system, the $\mathrm{KMgCa}$ ratio will remain higher than $20 \%$ and $c_{\text {ur }}$ will be greater than $1 \mathrm{kPa}$ even at very low salt contents $(<2 \mathrm{~g} / \mathrm{l})$.

Today, in the natural state, the concentration of $\mathrm{K}^{+}$is normally higher in the weathered dry crust and upper clay profiles than in the deeper part of the sediments, inhibiting quick behaviour in the top soil (Rosenquist, 1955). In normally consolidated clay profiles, the top soil may have an over-consolidation ratio 
(OCR) larger than 1 due to capillary suction in the unsaturated dry crust and the weathering and percolating of fresh water that, over centuries, have fed the clay-water system with stabilising cations. Pore-water compositions dominated by cations of higher valence or a smaller hydrated radius than $\mathrm{Na}^{+}$have a greater impact on suppressing the DDL around the clay particles, as do high salt contents (Figure 1(a)). The decreased repulsion between the clay particles allows the particles to move closer together before the structure breaks down, increasing the apparent pre-consolidation stress $\left(p_{\mathrm{c}}^{\prime}\right)$ (Figure 1(b)). Thus, the clay may take higher loads before large deformations occur when the DDL thickness decreases, and the shear strength therefore increases (Kenney et al., 1967; Santamarina et al., 2002). The shear strength is related to $p_{\mathrm{c}}^{\prime}$ and increases with increasing PI, and the compressibility decreases with increasing shear strength and plasticity (Bjerrum, 1967; Bjerrum and Rosenqvist, 1956). The PI in clays normally increases with increasing salt content (Løken, 1968). Therefore, increased salt content should also induce less deformations during loading, and increased $p_{\mathrm{c}}^{\prime}$ and shear strength. However, it is not known at what PI, salt content or pore-water composition the improvement commences, which is now discussed.

\section{Improved geotechnical properties}

\subsection{Site investigations and laboratory tests}

High-quality mini-block samples (downsized Sherbrooke block samples; see Emdal et al. (2016) for further details) were extracted from the quick-clay deposit at Dragvoll to determine the original geotechnical properties before the salt wells were installed. The fall-cone undrained shear strength $\left(c_{\mathrm{u}}\right)$, remoulded shear strength $\left(c_{\text {ur }}\right)$, water content $(w)$, Atterberg limits and pore-water chemistry were determined. Constant rate of strain oedometer (CRS) tests and anisotropically consolidated, undrained compression triaxial $\left(\mathrm{CAU}_{\mathrm{c}}\right)$ tests were conducted to determine the apparent pre-consolidation stress $\left(p_{\mathrm{c}}^{\prime}\right)$, OCR, deformations at applied loads and peak undrained shear strength $\left(c_{\mathrm{uc}}\right)$. The CRS tests were conducted with a strain rate of $0.75 \% / \mathrm{h}$. The $\mathrm{CAU}_{\mathrm{c}}$ tests were anisotropically consolidated to the effective overburden stresses $\left(\sigma_{\mathrm{v} 0}^{\prime}\right)$ applying a coefficient at rest $\left(K_{0}^{\prime}\right)$ of $0 \cdot 7$. The samples were consolidated for approximately $16 \mathrm{~h}$ before applying a backpressure of $250 \mathrm{kPa}$ and left to rest prior to shearing at a strain rate of $1.5 \% / \mathrm{h}$.

Salt from the wells was allowed to migrate into the clay thorough slotted sections from $4 \mathrm{~m}$ to $8 \mathrm{~m}$ depth. The migration was self-driven by diffusion, with a small advective component due to density gradients between the high-saline wells and the low-saline pore water in the surrounding clay volume. Pockets and discontinuous layers of slightly coarser material (more silt) caused a moderately non-symmetric salt migration around the wells, mainly dominated by diffusion. Further details of the site and installations are provided elsewhere (Helle et al., 2017a).
Two years and 5 months after installation of the salt wells, a mini-block sample was extracted from one borehole $0.5 \mathrm{~m}$ from salt well number 1 (SW1) at $4 \cdot 4-4 \cdot 8 \mathrm{~m}$ depth. Undisturbed $54 \mathrm{~mm}$ piston samples were extracted 3 years and 2 months after installation from 4.0-8.8 $\mathrm{m}$ depth in four boreholes (P7A, P7B, P7C and P7D) positioned $0.5 \mathrm{~m}$ from salt well number 7 (SW7) and from $5 \cdot 0-7 \cdot 8 \mathrm{~m}$ depth in one borehole positioned $1.0 \mathrm{~m}$ (P7E) from SW7 (Figure 3). All the samples except the mini-block $0.5 \mathrm{~m}$ from $\mathrm{SW} 1$ were tested in the laboratory on the same day as they were extracted from the ground to minimise storage effects on the results. The miniblock $0.5 \mathrm{~m}$ from SW1 was tested within $48 \mathrm{~h}$ after extraction. Fall-cone undrained and remoulded shear strengths, Atterberg limits and pore-water chemistry were determined for all the samples. $\mathrm{CAU}_{\mathrm{c}}$ and $\mathrm{CRS}$ tests were conducted on the salttreated clay at $4.4-4.8 \mathrm{~m}$ depth $0.5 \mathrm{~m}$ from SW1, and CRS tests were conducted on the samples extracted from $5 \cdot 0-5 \cdot 8 \mathrm{~m}$ depth around SW7. The quality of the tests was evaluated based on the difference in void ratio from the start of the test $\left(e_{0}\right)$ to the void ratio at an in situ effective overburden stress $\left(\Delta e / e_{0}\right)$ (Lunne et al., 1997a). All the tests conducted on specimens from the mini-blocks were of 'very good to excellent quality' $\left(\Delta e / e_{0}<0.04\right.$ at OCR $\left.1-2\right)$, with the exception of the triaxial test at $7.89 \mathrm{~m}$ which was of 'good to fair quality' $\left(\Delta e / e_{0}=0.04-0.07\right.$ at OCR 1-2). The CRS tests on the $54 \mathrm{~mm}$ specimens from boreholes P7A and P7D were of 'good to fair quality', whereas the tests from P7B, P7C and P7E were of poor quality and are therefore not included herein.

In addition to the in situ experiment, mini-block samples were extracted from the quick-clay deposit at the Dragvoll research site and stored in $\mathrm{KCl}$ slurry for a couple of months to study

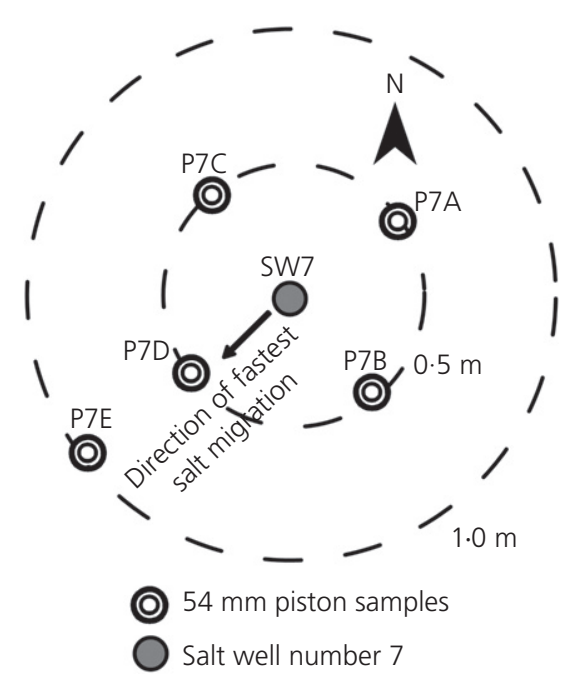

Figure 3. Locations of boreholes around salt well no. 7; $54 \mathrm{~mm}$ piston samples were extracted $0.5 \mathrm{~m}$ and $1.0 \mathrm{~m}$ from SW7 3 years and 2 months after installation. The direction of the fastest salt migration is indicated in the figure 
the impact of high concentrations of $\mathrm{KCl}$ on the geotechnical properties (Bryntesen, 2014; Helle et al., 2015). The parallel samples were stored wrapped in plastic film submerged in deionised and de-aired water to account for storage effects. Index testing, $\mathrm{CAU}_{\mathrm{c}}$ and CRS tests, as well as determination of the pore-water composition, were carried out on all samples stored in the containers.

\subsection{Changed pore-water chemistry and improved geotechnical properties}

The salt content in the original quick clay was only $0 \cdot 6-0 \cdot 7 \mathrm{~g} / \mathrm{l}$, with sodium $\left(\mathrm{Na}^{+}\right)$constituting approximately $85-92 \%$ of the major cations in the pore water (Table 1). Initially the quick clay had a remoulded shear strength $\left(c_{\mathrm{ur}}\right)$ of $<0.1 \mathrm{kPa}$ to $0.5 \mathrm{kPa}$, a PI of $4 \cdot 4-6.3 \%$ and a LI of $3.4-4.3$. The fall-cone undrained shear strength $\left(c_{\mathrm{u}}\right)$ was much lower than the peak undrained shear strength $\left(c_{\mathrm{uc}}\right)$ determined from the $\mathrm{CAU}_{\mathrm{c}}$ tests; $8-16 \mathrm{kPa}$ and around $27.5 \mathrm{kPa}$, respectively (Figure 4). The apparent pre-consolidation stress $\left(p_{\mathrm{c}}^{\prime}\right)$ in the original quick clay was $85 \mathrm{kPa}$ at $4.78 \mathrm{~m}$ depth and $67 \mathrm{kPa}$ at
$5.78 \mathrm{~m}$ depth, with corresponding OCRs of 1.8 and 1.2 . The oedometer modulus $\left(M_{\mathrm{OC}}\right)$ at stresses below $p_{\mathrm{c}}^{\prime}$ was around $5 \mathrm{MPa}$ (Figure 5).

The total salt content in the clay extracted $0.5 \mathrm{~m}$ from SW1 was after 2 years and 5 months increased from $0.7 \mathrm{~g} / 1$ to $1.6 \mathrm{~g} / \mathrm{l}$, and the pore-water composition was changed compared to that of the original quick clay, having a $\mathrm{KMgCa}$ ratio of $25 \%$ (all concentrations are in meq/l) (Table 1 ). The clay was no longer quick, having a $c_{\mathrm{ur}}$ of $1.8 \mathrm{kPa}$, LI of 1.6 (still higher than 1.2 due to a liquid limit lower than the natural water content) and PI of $12 \cdot 8 \%$ (Table 2). Even though the index parameters were improved, the $p_{\mathrm{c}}^{\prime}$ was the same as that of the quick clay ( $85 \mathrm{kPa}$ (Figure $5(\mathrm{a})$ ) and there was no improvement in $c_{\mathrm{uc}}$ or the post-peak strength in the $\mathrm{CAU}_{\mathrm{c}}$ test.

The salt content in the pore water from the clay samples around SW7 showed that the salt migrated faster in the direction of boreholes P7D and P7E (Figure 3) and also migrated faster with depth in all directions (Figure 6(c)). At $5.25 \mathrm{~m}$

Table 1. Pore-water chemistry in the original quick clay and salt-treated clays

\begin{tabular}{|c|c|c|c|c|c|}
\hline & $\begin{array}{l}\text { Quick clay } \\
4.7-5.0 \mathrm{~m}\end{array}$ & $\begin{array}{c}\text { Salt-treated SW1 } \\
4.4-4.8 \mathrm{~m}\end{array}$ & $\begin{array}{l}\text { Quick clay } \\
5.7-6.0 \mathrm{~m}\end{array}$ & $\begin{array}{c}\text { Salt-treated P7A } \\
5.0-5.8 \mathrm{~m}\end{array}$ & $\begin{array}{c}\text { Salt-treated P7D } \\
5.0-5.8 \mathrm{~m}\end{array}$ \\
\hline Salt content: g/l & 0.7 & $1 \cdot 6$ & 0.6 & $9 \cdot 7$ & $27 \cdot 7$ \\
\hline Sodium $\left(\mathrm{Na}^{+}\right):$meq/l & $7 \cdot 83$ & $20 \cdot 59$ & $7 \cdot 50$ & $32 \cdot 81$ & $40 \cdot 85$ \\
\hline Potassium $\left(\mathrm{K}^{+}\right)$: meq/l & $0 \cdot 30$ & 1.09 & $0 \cdot 24$ & $79 \cdot 33$ & $291 \cdot 29$ \\
\hline Magnesium $\left(\mathrm{Mg}^{2+}\right)$ : meg/l & 0.41 & $4 \cdot 14$ & $0 \cdot 18$ & $25 \cdot 14$ & $33 \cdot 74$ \\
\hline Calcium $\left(\mathrm{Ca}^{2+}\right):$ meq/l & $0 \cdot 33$ & $1 \cdot 56$ & $0 \cdot 22$ & 11.41 & $15 \cdot 77$ \\
\hline Chloride $\left(\mathrm{Cl}^{-}\right)$: meq/l & 0.27 & $17 \cdot 91$ & 0.27 & $144 \cdot 75$ & $407 \cdot 17$ \\
\hline Alkalinity: meq/l & 8.07 & $5 \cdot 28$ & $7 \cdot 16$ & $2 \cdot 76$ & $3 \cdot 52$ \\
\hline Pore water $\mathrm{pH}$ & $8 \cdot 60$ & $8 \cdot 62$ & $8 \cdot 76$ & 8.03 & 8.08 \\
\hline KMgCa ratio: \% & 12 & 25 & 8 & 78 & 89 \\
\hline
\end{tabular}

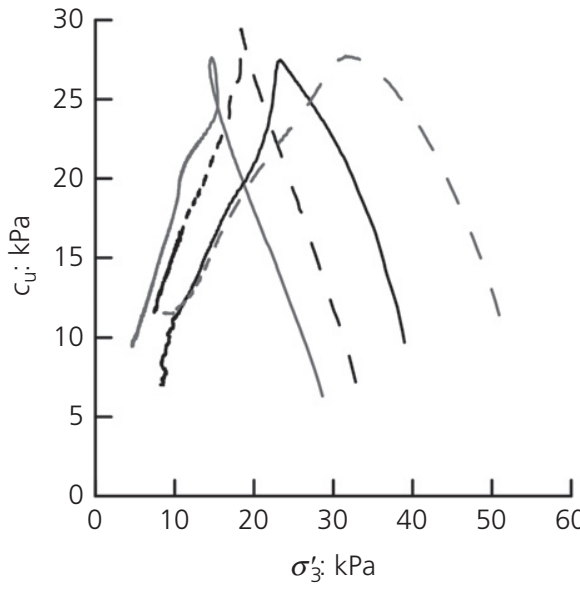

(a)

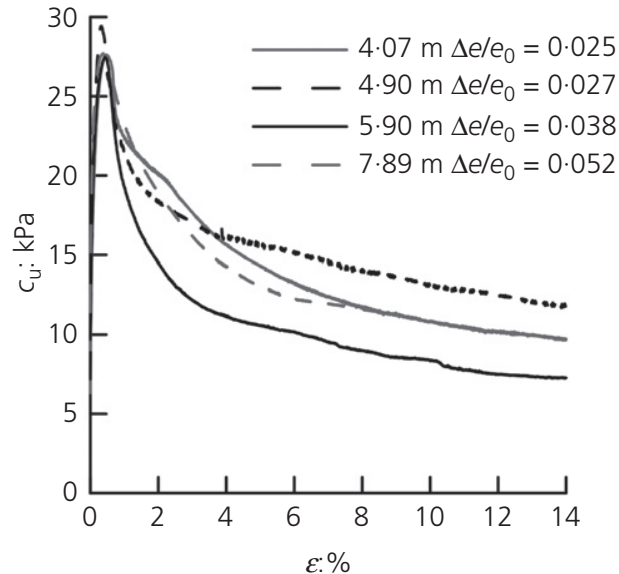

(b)

Figure 4. Triaxial testing of original quick clay. Undrained shear strength $\left(c_{u}\right)$ plotted against $(a)$ effective horizontal stress $\left(\sigma_{3}^{\prime}\right)$ and (b) vertical strain $(\varepsilon)$ 


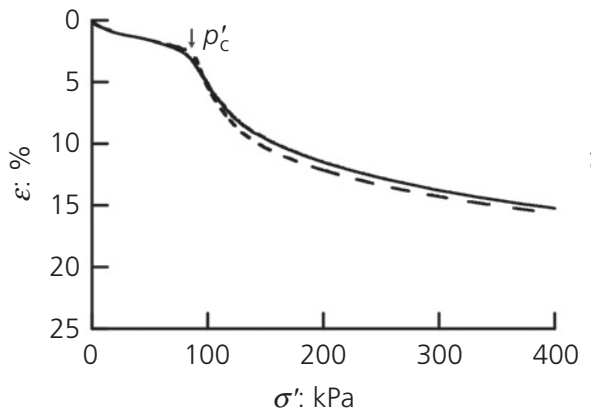

(a)

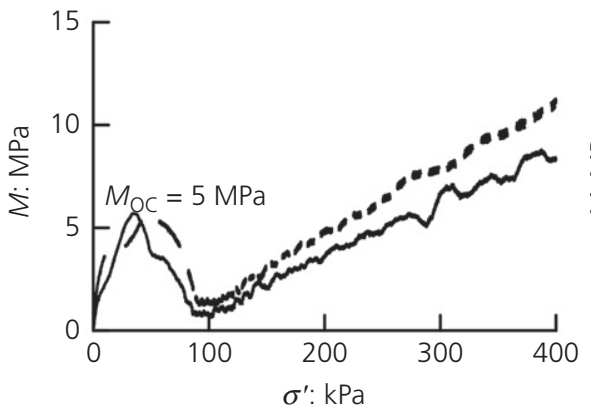

(b)

SW1

- - Quick clay, $0.7 \mathrm{~g} / \mathrm{l}(4.78 \mathrm{~m}), \Delta \mathrm{e} / \mathrm{e}_{0}=0.028$

$1.6 \mathrm{~g} / \mathrm{l}(4.53 \mathrm{~m}), \Delta \mathrm{e} / \mathrm{e}_{0}=0.029$

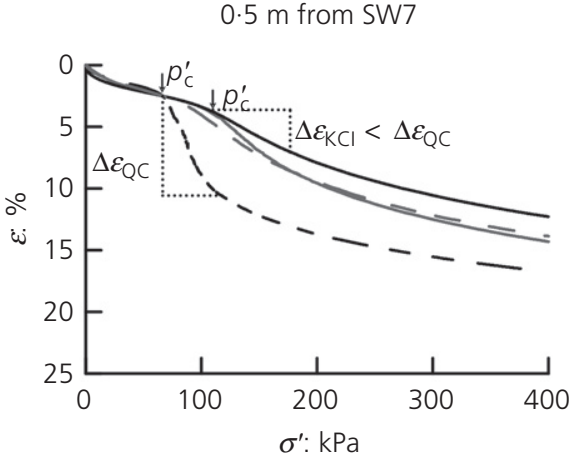

(c)

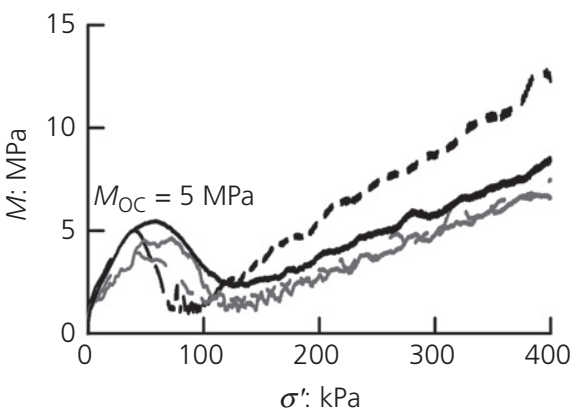

(d)

SW7

- Quick clay, $0.6 \mathrm{~g} / \mathrm{l}(5.78 \mathrm{~m}) \Delta \mathrm{e} / \mathrm{e}_{0}=0.035$

- $-9.7 \mathrm{~g} / \mathrm{l}($ P7A $5.43 \mathrm{~m}), \Delta e / \mathrm{e}_{0}=0.040$

$27.7 \mathrm{~g} / \mathrm{l}(33.0 \mathrm{~g} / \mathrm{l}$ ?, P7D $5.43 \mathrm{~m}), \Delta \mathrm{e} \mathrm{e}_{0}=0.042$

$27.7 \mathrm{~g} / \mathrm{l}(35.0 \mathrm{~g} / \mathrm{l}$ ?, P7D $5.48 \mathrm{~m}), \Delta e / \mathrm{e}_{0}=0.045$

Figure 5. Oedometer results from original quick clay and salt-treated clay. (a) Strain $(\varepsilon)$ and (b) oedometer stiffness $(M)$ plotted against applied effective vertical stress $\left(\sigma^{\prime}\right)$ on mini-block sample extracted $0.5 \mathrm{~m}$ from SW 1 at $4.5-4.8 \mathrm{~m}$ depth. (c) $\varepsilon$ and (d) $M$ plotted against $\sigma$ on $54 \mathrm{~mm}$ samples extracted $0.5 \mathrm{~m}$ from SW7 at 5.4-5.8 m depths. The apparent pre-consolidation stress ( $\left.p_{c}^{\prime}\right)$ is indicated in (a) and (b). The immediate collapse of the structure at loads beyond $p_{c}^{\prime}$ was decreased in the $\mathrm{KCl}$-treated clay $\left(\Delta \varepsilon_{\mathrm{KCl}}\right)$ compared with the original quick clay $\left(\Delta \varepsilon_{\mathrm{QC}}\right)$. ?, values are not measured, but estimated

Table 2. Geotechnical properties of the original quick clay and salt-treated clays. The depths relate to the CRS tests of the samples extracted from depths given in Table 1

\begin{tabular}{|c|c|c|c|c|c|c|}
\hline & $\begin{array}{l}\text { Quick clay } \\
4.78 \mathrm{~m}\end{array}$ & $\begin{array}{c}\text { Salt-treated SW1 } \\
4.53 \mathrm{~m}\end{array}$ & $\begin{array}{l}\text { Quick clay } \\
5.78 \mathrm{~m}\end{array}$ & $\begin{array}{c}\text { Salt-treated P7A } \\
5.43 \mathrm{~m}\end{array}$ & $\begin{array}{c}\text { Salt-treated P7D } \\
5.43 \mathrm{~m}\end{array}$ & $\begin{array}{c}\text { Salt-treated P7D } \\
5.48 \mathrm{~m}\end{array}$ \\
\hline Salt content: g/l & 0.7 & 1.6 & 0.6 & $9 \cdot 7$ & $27 \cdot 7$ (33?) & $27 \cdot 7$ (35?) \\
\hline w: \% & $37 \cdot 7$ & $38 \cdot 2$ & $36 \cdot 6$ & $37 \cdot 8$ & 37.7 & 37.5 \\
\hline$\rho: \mathrm{g} / \mathrm{cm}^{3}$ & 1.89 & 1.88 & 1.89 & 1.88 & 1.87 & 1.87 \\
\hline PI: \% & $4 \cdot 4$ & $12 \cdot 8$ & $5 \cdot 4$ & 21.9 & $24 \cdot 0$ & $24 \cdot 0$ \\
\hline LI & 3.9 & 1.6 & $4 \cdot 3$ & $0 \cdot 8$ & 0.6 & 0.6 \\
\hline $\mathrm{C}_{\mathrm{u}}: \mathrm{kPa}$ & $13 \cdot 9$ & $11 \cdot 1$ & $8 \cdot 6$ & $24 \cdot 0$ & $28 \cdot 6$ & $28 \cdot 6$ \\
\hline$c_{u r}: \mathrm{kPa}$ & $0 \cdot 3$ & $1 \cdot 8$ & $0 \cdot 1$ & $4 \cdot 7$ & $5 \cdot 1$ & $5 \cdot 1$ \\
\hline$c_{u c}: \mathrm{kPa}$ & $27 \cdot 5$ & $26 \cdot 6$ & $27 \cdot 5$ & - & - & - \\
\hline$\sigma_{\mathrm{v} 0}^{\prime}: \mathrm{kPa}$ & $46 \cdot 6$ & $44 \cdot 4$ & $55 \cdot 3$ & $52 \cdot 2$ & $52 \cdot 2$ & $52 \cdot 7$ \\
\hline$p_{c}^{\prime}: \mathrm{kPa}$ & $85 \cdot 0$ & $85 \cdot 0$ & $67 \cdot 0$ & $90 \cdot 0$ & $110 \cdot 0$ & $110 \cdot 0$ \\
\hline OCR & $1 \cdot 8$ & 1.9 & $1 \cdot 2$ & $1 \cdot 7$ & $2 \cdot 1$ & $2 \cdot 1$ \\
\hline
\end{tabular}

?, values are not measured, but estimated

depth, the salt contents were $9.7 \mathrm{~g} / 1$ for P7A and $27.7 \mathrm{~g} / 1$ for $\mathrm{P} 7 \mathrm{D} ; \mathrm{Na}^{+}$was depleted and the $\mathrm{KMgCa}$ ratios were $78 \%$ and $89 \%$, respectively (Table 1 ). The increased salt contents and concentrations of $\mathrm{K}^{+}, \mathrm{Mg}^{2+}$ and $\mathrm{Ca}^{2+}$ improved the $c_{\text {ur }}$ way beyond what is considered to be quick, to around $5 \mathrm{kPa}$ (Figure 6(a)). The fall-cone undrained shear strength increased 


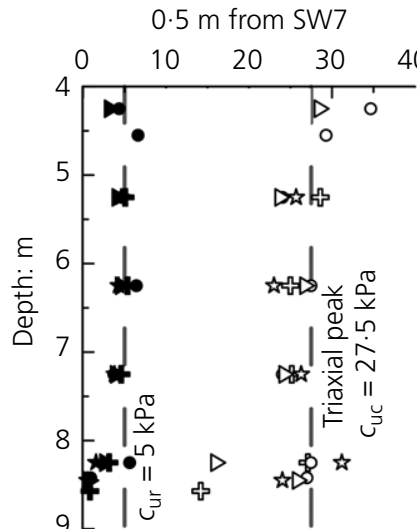

(a)

Undrained and remoulded shear strength: $\mathrm{kPa}$

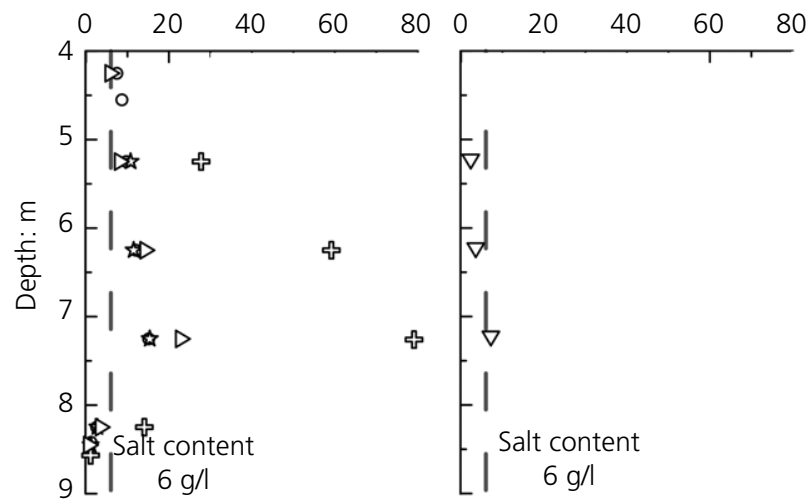

(c)

Salt content: $g / l$

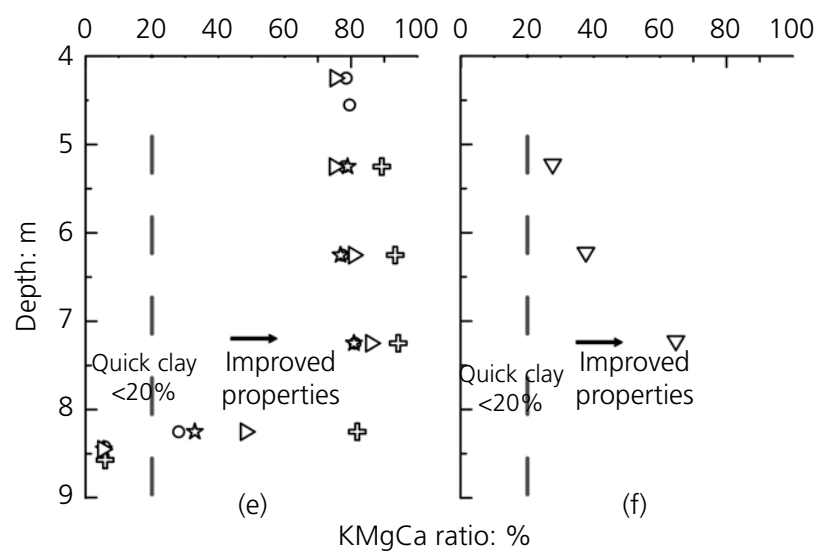

$\circ 0.5 \mathrm{~m}$ (P7A) $\triangleright 0.5 \mathrm{~m}$ (P7C) $\nabla 1.0 \mathrm{~m}$ (P7E) \& $0.5 \mathrm{~m}(\mathrm{P} 7 \mathrm{~B})$ \& $0.5 \mathrm{~m}$ (P7D)

Figure 6. Fall-cone undrained shear strength (open symbols) and remoulded shear strength (filled symbols) in samples P7A, P7B, P7C and P7D $0.5 \mathrm{~m}$ from SW7 (a) and P7E $1.0 \mathrm{~m}$ from SW7 (b). Salt contents $0.5 \mathrm{~m}$ from SW7 (c) and $1.0 \mathrm{~m}$ from SW7 (d). $\mathrm{KMgCa}$ ratio $0.5 \mathrm{~m}$ from SW7 (e) and $1.0 \mathrm{~m}$ from SW7(f)

up to around $25 \mathrm{kPa}$, close to the $c_{\mathrm{uc}}$ value found in the $\mathrm{CAU}_{\mathrm{c}}$ tests (around $27.5 \mathrm{kPa}$ ). This implies that the specimens used for fall-cone testing, cut from the $54 \mathrm{~mm}$ piston samples extracted from the salt-treated clay, were less disturbed than

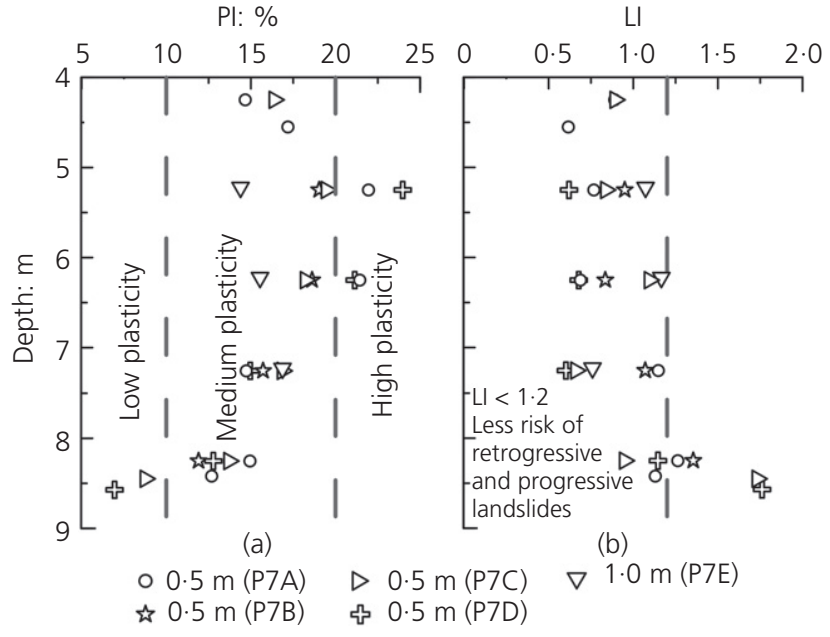

Figure 7. PI (a) and $\mathrm{LI}(\mathrm{b})$ in boreholes P7A, P7B, P7C and P7D (0.5 m from SW7) and P7E (1.0 m from SW7)

those cut from the quick-clay samples. The PI of the clay was improved from low to medium and high (Figure 7(a)) and the LI in the salt-treated clay decreased to $0 \cdot 6-0 \cdot 8$ in the samples used for CRS tests (Figure 7(b) and Table 2). The apparent pre-consolidation stress increased from $67 \mathrm{kPa}$ in the original quick clay to $90 \mathrm{kPa}$ at a salt content of $9.7 \mathrm{~g} / 1$ and to $110 \mathrm{kPa}$ at a salt content of $27.7 \mathrm{~g} / \mathrm{l}$, with a corresponding increase in the OCR from $1 \cdot 2$ to $1 \cdot 7-2 \cdot 1$. The oedometer modulus $\left(M_{\mathrm{OC}}\right)$ was practically unchanged (Figure 5(d)). The observed decrease in $M_{\mathrm{OC}}$ in two of the salt-treated clay specimens at $5.43 \mathrm{~m}$ depth is most likely due to the fact that the $54 \mathrm{~mm}$ piston samples were of poorer quality than the mini-block samples extracted in the quick clay. The immediate deformation at loads exceeding $p_{\mathrm{c}}^{\prime}$ was far less in the salt-treated clay $\left(\Delta \varepsilon_{\mathrm{KCl}}\right.$ in Figure $\left.5(\mathrm{c})\right)$ than in the quick clay $\left(\Delta \varepsilon_{\mathrm{QC}}\right)$. There was a difference in the compressibility at loads beyond $p_{\mathrm{c}}^{\prime}$ in the specimens with a salt content of $27.7 \mathrm{~g} / 1$ ('P7D $5.43 \mathrm{~m}$ ' and 'P7D $5.48 \mathrm{~m}$ '). The sample quality of these samples was 'good to fair'; 0.042 and $0 \cdot 045$, respectively. The salt content increased with depth, and the above described pore-water composition was from $5.25 \mathrm{~m}$ depth, whereas the oedometer tests were conducted on samples from $5.43 \mathrm{~m}$ and $5.48 \mathrm{~m}$ depth. The salt content at $6.25 \mathrm{~m}$ depth was $59 \cdot 1 \mathrm{~g} / \mathrm{l}$. Assuming a linear increase in salt content with depth, the salt contents in the oedometer specimens may have been higher; approximately $33 \mathrm{~g} / 1$ and $35 \mathrm{~g} / 1$. The difference in the salt content is small and does not explain the difference in compressibility. Thin silt layers (millimeters thickness) were found in the whole sediment package with centimeters distance. This may have caused the small difference in deformations between these two specimens at loads beyond $p_{\mathrm{c}}^{\prime}$ (Figure 5(c)).

\section{Discussion}

Salt wells filled with $\mathrm{KCl}$ were installed in a highly sensitive quick-clay deposit to study the impact of changed pore-water 
chemistry on geotechnical properties in order to validate $\mathrm{KCl}$ wells as a landslide-mitigation method. The most common quick-clay landslide types are either retrogressive or progressive. Retrogressive development may be inhibited by a remoulded shear strength $\left(c_{\mathrm{ur}}\right)$ larger than $1 \mathrm{kPa}$ and a LI lower than 1.2 as the slide debris will not flow out of the slide pit, which reduces the risk of successive back-scarp failures. The $c_{\text {ur }}$ values of the clay samples extracted around SW7 seemed to stabilise at around $5 \mathrm{kPa}$ and the fall-cone shear strength $\left(c_{\mathrm{u}}\right)$ was around $25 \mathrm{kPa}$ at salt contents exceeding $6 \mathrm{~g} / \mathrm{l}$ and a $\mathrm{KMgCa}$ ratio exceeding $80 \%$ (Figure 6). According to Helle et al. (2017a), clay ceases to be quick, reaches $c_{\text {ur }}>1 \mathrm{kPa}$ and $\mathrm{LI}<1 \cdot 2$, and changes from low to medium plasticity when the $\mathrm{KMgCa}$ ratio in the pore water exceeds $20 \%$, thus inhibiting retrogressive development and reducing the post-failure movement of progressive landslides. The initiation of progressive landslides depends, however, on the strain-softening behaviour of the clay around peak shear strength.

Reintroducing high salt contents to the highly sensitive quick clays at Dragvoll increased the apparent pre-consolidation stress $\left(p_{\mathrm{c}}^{\prime}\right)$ and thus also the OCR. At salt contents of $9.7 \mathrm{~g} / 1$ and $27 \cdot 7 \mathrm{~g} / 1$, the salt-treated clays had a $c_{\text {ur }}$ of $4 \cdot 7-5 \cdot 1 \mathrm{kPa}$, LI of $0.6-0.8$ and the clays were of high plasticity; the $p_{\mathrm{c}}^{\prime}$ increased from $67 \mathrm{kPa}$ to $90 \mathrm{kPa}$ and $110 \mathrm{kPa}$, respectively. Loading the samples just beyond $p_{\mathrm{c}}^{\prime}$, the deformations in the in situ salt-treated clay samples were significantly reduced compared with the rapid structural collapse and immediate large deformations seen in the original quick clay. Highly sensitive quick clays have a characteristic strain-softening behaviour with a distinct peak undrained shear strength $\left(c_{\mathrm{uc}}\right)$ and a rapid collapse of the structure after peak, thus dramatically reducing their post-peak strength (Figure 4). The slower collapse of the structure and decreased deformations at loads just beyond $p_{\mathrm{c}}^{\prime}$ seen in the CRS tests on the salt-treated clay may imply that brittleness (softening after peak) was reduced and that the clay may have a higher post-peak strength at deformations exceeding the strain at failure. Compared with the original quick clay, the $c_{\text {ur }}$ increased from $0.3 \mathrm{kPa}$ to $1.8 \mathrm{kPa}$ for a $\mathrm{KMgCa}$ ratio of $25 \%$. The post-failure properties $\left(c_{\mathrm{ur}}\right.$ and Atterberg limits) were improved even at low salt contents $(<2 \mathrm{~g} / \mathrm{l})$ due to the favourable pore-water composition. However, at such low salt contents the deformations at increasing loads were the same as in the quick clay and the values of $p_{\mathrm{c}}^{\prime}$ and $c_{\mathrm{uc}}$ were unchanged.

The salt contents of the mini-block samples stored in $\mathrm{KCl}$ slurry were much higher than found in the in situ experiment at Dragvoll (170-260 g/l), thus increasing the bulk and dry densities of the clay due to the introduction of more solids. The bulk and dry densities of the samples extracted around SW7 with salt contents up to $27 \cdot 7 \mathrm{~g} / 1$ were, however, unaltered. Thus, for the samples stored in $\mathrm{KCl}$ slurry, some of the effect on the decreased deformation at loads beyond $p_{\mathrm{c}}^{\prime}$ may, at very high salt contents $(\succsim 80 \mathrm{~g} / \mathrm{l})$, be induced by increased solids in the voids in addition to maximum suppression of the DDL. Nevertheless, the oedometer stress-strain curves of the samples stored in $\mathrm{KCl}$ slurry and the clays treated in situ corresponded quite well. In addition to decreased deformation and improved $p_{\mathrm{c}}^{\prime}$ and OCR in the oedometer tests, the peak and post-peak undrained shear strength both increased in the samples stored in $\mathrm{KCl}$ slurry compared with the samples stored in de-ionised and de-aired water (Figure 8), which may reduce the risk of progressive landslides.

The progressive development of landslides in highly sensitive quick clays may be explained by a two-part process (Jostad and Grimstad, 2011). The first part is the initiation of progressive failure along a shear band and the second part comprises post-failure movement. At initiation of failure along a failure plane, peak strength is mobilised. A progressive landslide may be initiated if the post-peak strength thereafter is sufficiently reduced, leading to a domino effect with subsequent deformations beyond strains at failure along a shear plane (Fornes, 2014; Gylland, 2014; Jostad et al., 2014; Thakur et al., 2014). Many authors suggest that the peak undrained shear strength is correlated to the OCR (e.g. Bjerrum, 1967; Karlsrud and Hernandez-Martinez, 2013; Ladd and Foott, 1974). Therefore, it is likely that the increased OCR of the in situ salt-treated clays is related to an increased peak-undrained shear strength $\left(c_{\mathrm{uc}}\right)$, thereby reducing the risk of initiation of progressive failure.

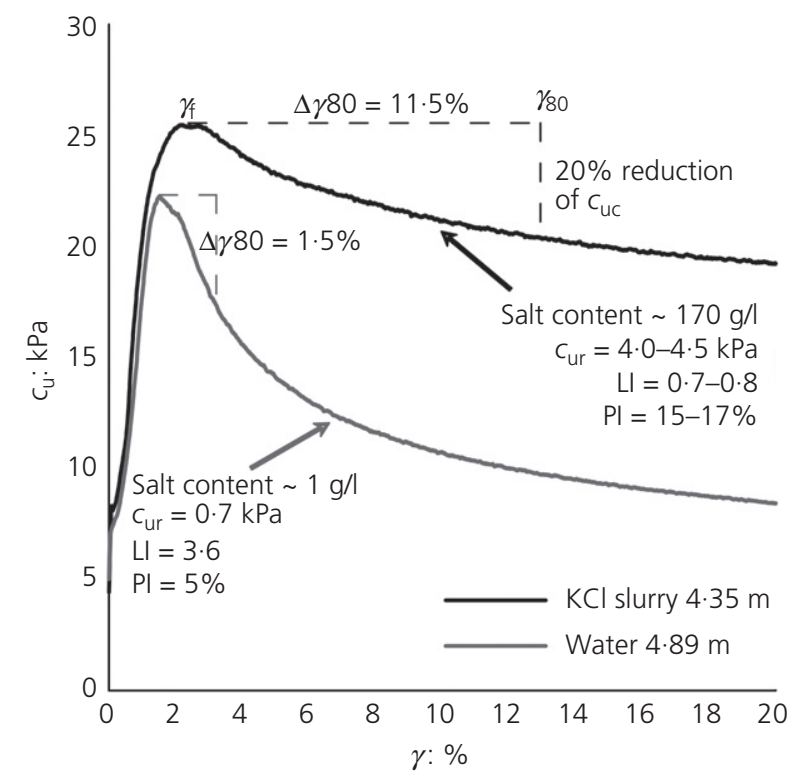

Figure 8. Triaxial test results of a sample stored in $\mathrm{KCl}$ slurry compared to a sample stored in de-aired water. The brittleness parameter $\left(\Delta \gamma_{80}\right)$ was found by subtracting the shear strain at failure $\left(\gamma_{f}\right)$ from the shear strain $\left(\gamma_{80}\right)$ found at $20 \%$ reduction of peak-strength $\left(c_{\mathrm{uc}}\right) . \Delta \gamma_{80}$ increased from $1.5 \%$ in the sample stored in de-ionised and de-aired water to $11.5 \%$ in the sample stored in $\mathrm{KCl}$ slurry 
The degree of softening after peak describes the brittleness of the clay. Fornes (2014) introduced the brittleness parameter $\Delta \gamma_{80}$, with values in the range $0-2 \%$ indicating high brittleness, $2-5 \%$ medium brittleness and $>5 \%$ low brittleness. $\Delta \gamma_{80}$ is defined as the difference between the shear strain $\left(\gamma_{80}\right)$ at $20 \%$ reduction of the undrained shear strength after peak and the shear strain at failure $\left(\gamma_{\mathrm{f}}\right)$. The peak undrained shear strength was improved and the post-peak undrained shear strength was significantly improved in the mini-block sample stored in $\mathrm{KCl}$ slurry having an OCR of $2 \cdot 7$. Furthermore, $\Delta \gamma_{80}$ increased from $1.5 \%$ in the sample stored in de-ionised and deaired water to $11.5 \%$ in the sample stored in $\mathrm{KCl}$ slurry, thus indicating a significant reduction in brittleness (Figure 8). The decreased collapse of the structure seen at loads exceeding $p_{\mathrm{c}}^{\prime}$ in the oedometer tests on the in situ salt-treated clay may be related to the reduced brittleness of the clay. Thus, installing $\mathrm{KCl}$ wells in quick-clay slopes may reduce the risk of the initiation of progressive failures and potential post-failure movements. The reduced risk of initiating progressive failures commences at larger salt contents and different $\mathrm{KMgCa}$ ratios than those needed to inhibit retrogressive landslide development.

Leaching tests on clay samples conducted by Torrance (1974) revealed larger compressibility (i.e. volume change as a response to loading) and a reduction in $p_{\mathrm{c}}^{\prime}$ in leached clays with sodium-dominated pore fluids with salt contents of less than $2 \mathrm{~g} / 1$ than in clays with higher salt contents. The results from the in-situ-treated Dragvoll clay imply that improved $p_{\mathrm{c}}^{\prime}$ and decreased compressibility commenced at salt contents less than $9 \mathrm{~g} / \mathrm{l}$. This may imply decreased deformations due to loading and increases in $p_{\mathrm{c}}^{\prime}, c_{\mathrm{uc}}$, post-peak strength and $\Delta \gamma_{80}$ at salt contents exceeding somewhere between $2 \mathrm{~g} / 1$ and $9 \mathrm{~g} / \mathrm{l}$.

The compressibility of clay influences the measured tip resistance in cone penetration tests because decreased compressibility increases the resistance against deformation, and thus penetration (Lunne et al., 1997b). Bjerrum (1967) and Sridharan and Nagaraj (2000) related decreasing compressibility to increasing plasticity. The samples treated in situ, with increased $p_{\mathrm{c}}^{\prime}$ and decreased deformations at loads just beyond $p_{\mathrm{c}}^{\prime}$, were of high plasticity, with PI in the range 21.9 $24.0 \%$. For the samples stored in $\mathrm{KCl}$ slurry, the PI was in the range $10 \cdot 0-17 \cdot 4 \%$. Correlations between the in situ test results from Dragvoll and laboratory-determined geotechnical properties showed that the measured tip resistance increased significantly at a $c_{\text {ur }}$ of around $3.5 \mathrm{kPa}$ (Helle et al., 2017b). A $c_{\text {ur }}$ of $3.5 \mathrm{kPa}$ corresponds to a PI of around $15 \%$, which was obtained at salt contents exceeding around $6 \mathrm{~g} / \mathrm{l}$, or at a $\mathrm{KMgCa}$ ratio exceeding $60 \%$, even at low salt contents (Figure 9). This may indicate that that the immediate deformations at loads exceeding $p_{\mathrm{c}}^{\prime}$ decrease and the post-peak shear strength improves at a $\mathrm{KMgCa}$ ratio exceeding $60 \%$ at low salt contents, or at salt contents larger than $6 \mathrm{~g} / \mathrm{l}$, due to significantly improved $c_{\mathrm{ur}}$ and PI.

The changed pore-water chemistry due to diffusion from the $\mathrm{KCl}$ wells had a great impact on improving the values of $c_{\mathrm{ur}}$, LI, PI, $p_{\mathrm{c}}^{\prime}$ and OCR and decreasing the immediate deformations and rapid destructuring of the clays at loads just beyond $p_{\mathrm{c}}^{\prime}$. The samples stored in $\mathrm{KCl}$ slurry showed a modest increase in peak shear strength. Nevertheless, the brittleness, as observed from the steepness of the stress-strain curve after peak, was significantly reduced. Therefore, changing the porewater chemistry by installing $\mathrm{KCl}$ wells in quick-clay slopes inhibits retrogressive landslide development and may also reduce the risk of the initiation of progressive landslides.

\section{Conclusions}

The diffusion of $\mathrm{KCl}$ from wells into quick clays was found to change the pore-water chemistry, leading to improved geotechnical properties. The remoulded shear strength $\left(c_{\mathrm{ur}}\right)$ increased

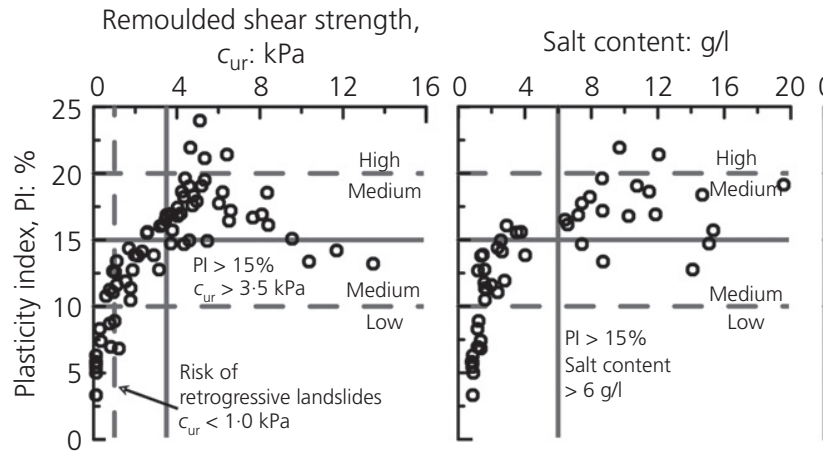

(a)

(b)

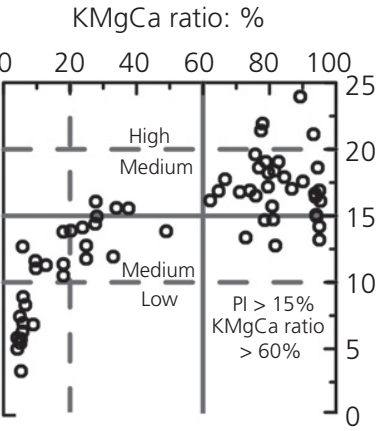

(c)

Figure 9. PI plotted against remoulded shear strength $\left(c_{\mathrm{ur}}\right)(\mathrm{a})$, salt content (shown up to $\left.20 \mathrm{~g} / \mathrm{l}\right)(\mathrm{b})$ and KMgCa ratio (c). The clay had low plasticity at $\mathrm{PI}<10 \%$, medium plasticity in the range $10-20 \%$ and high plasticity at PI $>20 \%$. Note that salt contents are only shown up to $20 \mathrm{~g} / \mathrm{l}$ even though salt contents up to $98 \mathrm{~g} / \mathrm{l}$ were found. The data suggest that $\mathrm{PI}>15 \%$ at $\mathrm{Cur}_{\mathrm{ur}}>3.5 \mathrm{kPa}$, at salt contents $>6 \mathrm{~g} / \mathrm{l}$ and/or KMgCa ratio $>60 \%$ 
beyond $1 \mathrm{kPa}$, the LI decreased below $1 \cdot 2$ and the plasticity of the clay changed from low to medium at $\mathrm{KMgCa}$ ratios exceeding $20 \%$; this is sufficient to inhibit retrogressive landslide development. The apparent pre-consolidation stress $\left(p_{\mathrm{c}}^{\prime}\right)$ increased and the immediate deformations at loads exceeding $p_{\mathrm{c}}^{\prime}$ decreased with increasing salt content. The increased $p_{\mathrm{c}}^{\prime}$ and OCR imply increased peak undrained shear strength. The decreased immediate deformations at loads exceeding $p_{\mathrm{c}}^{\prime}$ indicate that the structure of the salt-treated clay would not collapse as rapidly as that seen in quick clays. This implies that the brittleness of the salt-treated clays decreased, which may reduce the risk of initiation of progressive landslides in quickclay areas. Brittleness may be reduced sufficiently when salt treatment provides $c_{\text {ur }}>3.5 \mathrm{kPa}$ and PI $>15 \%$, which commenced at a $\mathrm{KMgCa}$ ratio exceeding $60 \%$ or at salt contents exceeding $6 \mathrm{~g} / \mathrm{l}$. Leaching of the salt-treated clay by groundwater will, with time after salt-well installation again, decrease the salt content in the pore water. However, groundwater is dominated by calcium and/or magnesium, both of which have a more favourable impact on suppressing the DDL thickness than sodium, which is the dominating cation in the pore water in quick clays. As sodium is washed out of the system, the repulsive forces between the clay particles in the leached salttreated clay will remain sufficiently low to prevent the clays from turning liquid when remoulded. Clays treated with $\mathrm{KCl}$ will therefore maintain a non-quick behaviour and improved plasticity even at low salt contents in the future.

Initial slides triggered in quick-clay slopes stabilised with $\mathrm{KCl}$ wells will not develop into large retrogressive landslides as the salt-treated clay barrier will prevent the clay from flowing out of the area when $c_{\mathrm{ur}}>1 \mathrm{kPa}$. The reduced collapse of the structure of salt-treated clays implies reduced brittleness, which may reduce the risk of progressive landslide development.

\section{Acknowledgements}

The authors express their sincere gratitude to $\mathrm{PhD}$ student Helene Alexandra Amundsen at the Norwegian University of Science and Technology (NTNU) for guidance in the laboratory and discussions of laboratory results. The great effort of Rikke N. Bryntesen (NTNU/now Norwegian Public Roads Administration) in carrying out the laboratory tests on the mini-blocks stored in $\mathrm{KCl}$ slurry is greatly appreciated. The authors also express gratitude to Jan Jønland, Gunnar Winther and Einar Husby (all NTNU) for carrying out the ground investigations and to Mufak Naoroz (Oslo University) for carrying out the pore-water chemistry analysis. $\mathrm{PhD}$ student Petter Fornes is acknowledged for discussions on progressive failures in quick clays. This work would not have been possible without funding from the Norwegian research programme 'Natural hazards: infrastructure for floods and slides (NIFS)' (http://www.naturfare.no), a collaboration between the Norwegian Public Roads Administration, the Norwegian Water Resources and Energy Directorate and the Norwegian Railways Administration.

\section{REFERENCES}

Bjerrum L (1955) Norske Marine Leirers Geotekniske Egenskaper. Norwegian Geotechnical Institute, Oslo, Norway, NGI Publication no. 7 (in Norwegian).

Bjerrum L (1967) Engineering geology of Norwegian normallyconsolidated marine clays as related to settlements of buildings. Géotechnique 17(2): 83-118, http://dx.doi.org/10.1680/geot.1967.17. 2.83 .

Bjerrum L and Rosenqvist IT (1956) Some experiments with artificially sedimented clays. Géotechnique 6(3): 124-136, http://dx.doi.org/ 10.1680/geot.1956.6.3.124.

Bryntesen RN (2014) Laboratory Investigation on Salt Migration and Its Effect on the Geotechnical Strength Parameters in Quick Clay Mini-Block Samples from Dragvoll. Master's thesis, Norwegian University of Science and Technology, Trondheim, Norway, pp. 1-105.

Eggestad A and Sem H (1976) Stability of excavations improved by salt diffusion from deep wells. Proceedings of the 6th European Conference on Soil Mechanics and Foundation Engineering, Vienna, Austria, ISSMFE Austrian National Committee, Vienna, Austria, pp. 211-216.

Emdal A, Gylland AS, Amundsen HA, Kåsin K and Long M (2016) Mini-block sampler. Canadian Geotechnical Journal 53(8): 1235-1245.

Fornes P (2014) NGIs Anbefalinger for Krav til Effekt av Sprøbruddoppførsel. Naturfare: infrastruktur, flom og skred (NIFS), Oslo, Norway, Report no. 88/2014 (in Norwegian).

Gjengedal I (2012) Laboratoriestudie av Saltdiffusjon i Kvikkleire. Master's thesis, Norwegian University of Science and Technology, Trondheim, Norway (in Norwegian).

Gylland AS (2014) The effect of deformation rate in progressive slope failure. In Landslides in Sensitive Clays: From Geoscience to Risk Management (L'Heureux JS, Locat A, Leroueil S, Demers D and Locat J (eds)). Springer, Dordrecht, the Netherlands, pp. 267-277.

Helle TE, Bryntesen RN, Amundsen HA et al. (2015) Laboratory setup to evaluate the improvement of geotechnical properties from potassium chloride saturation of a quick clay from Dragvoll, Norway. In Proceedings of 68th Canadian Geotechnical Conference GeoQuebec 2015, Quebec, Canada (Côté J and Allard M (eds)). Agora Communication Inc., Quebec, QC, Canada.

Helle TE, Nordal S, Aagaard P and Lied OK (2016) Long-term effect of potassium chloride treatment on improving the soil behavior of highly sensitive clay - Ulvensplitten, Norway. Canadian Geotechnical Journal 53(3): 410-422.

Helle TE, Aagaard P and Nordal S (2017a) In-situ improvement of highly sensitive clays by potassium chloride migration. Journal of Geotechnical and Geoenvironmental Engineering ASCE 143(10): 1-13.

Helle TE, Long M, Nordal S and Aagaard P (2017b) Effectiveness of resistivity cone penetration tests in salt-treated highly sensitive clay. Proceedings of the Institute of Civil Engineers - Ground Improvement 170(3): 173-184, http://dx.doi.org/10.1680/ jgrim.17.00017.

Jostad HP and Grimstad G (2011) Comparison of distribution functions for the nonlocal strain approach. Proceedings of the 2 nd International Symposium on Computational Geomechanics, Cavtat-Dubrovnik, Croatia (Pietruszczak S and Pande GN (eds)). $\mathrm{IC}_{2} \mathrm{E}$ International Centre for Computational Engineering, Rhodes, Greece, pp. 212-223 (CD-ROM).

Jostad HP, Fornes P and Thakur V (2014) Effect of strain-softening in design of fills on gently inclined areas with soft sensitive clays. In Landslides in Sensitive Clays: From Geoscience to Risk Management (L'Heureux JS, Locat A, Leroueil S, Demers D and Locat J (eds)). Springer, Dordrecht, the Netherlands, pp. $305-316$. 
Karlsrud K and Hernandez-Martinez FG (2013) Strength and deformation properties of Norwegian clays from laboratory tests on high-quality block samples. Canadian Geotechnical Journal 50(12): 1273-1293

Kenney TC, Moum J and Berre T (1967) An experimental study of bonds in natural clay. Proceedings of Geotechnical Conference, Oslo, Norway (Jørstad FA (ed.)). Norwegian Geotechnical Institute, Oslo, Norway, pp. 65-69.

Ladd CC and Foott R (1974) New design procedure for stability of soft clays. Journal of the Geotechnical Engineering Division ASCE 100(7): 763-786.

Leroueil S and Vaughan PR (1990) The general and congruent effects of structure in natural soils and weak rocks. Géotechnique 40(3): 467-488, http://dx.doi.org/10.1680/ geot.1990.40.3.467.

Leroueil S, Tavenas F and Le Bihan JP (1983) Proprietes caracteristiques des argiles de l'est du Canada. Canadian Geotechnical Journal 20(4): 681-705 (in French).

Løken T (1968) Kvikkleiredannelse og Kjemisk Forvitring i Norske Leirer. Norwegian Geotechnical Institute, Oslo, Norway, NGI Publication no. 75 (in Norwegian).

Løken T (1970) Recent research at the Norwegian Geotechnical Institute concerning the influence of chemical additions on quick clay. Geologiska Föreningen i Stockholm Förhandlingar 92(2): 133-147.

Lunne T, Berre T and Strandvik S (1997a) Sample disturbance effects in soft low plastic Norwegian clay. In Proceedings of Recent Developments in Soil and Pavement Mechanics, Rio de Janeiro, Brazil (Almeida M (ed.)). Balkema, Amsterdam, the Netherlands, pp. 81-102.

Lunne T, Robertson PK and Powell JJM (1997b) Cone Penetration Testing in Geotechnical Practice. Spon Press, London, UK.

Mitchell JK and Soga K (2005) Fundamentals of Soil Behaviour, 3rd edn. Wiley, Hoboken, NJ, USA.

Moore DM and Reynolds RC Jr (1997) X-ray Diffraction and the Identification and Analysis of Clay Minerals, 2nd edn. Oxford University Press, Inc., New York, NY, USA.

Moum J, Sopp OI and Løken T (1968) Stabilization of Undisturbed Quick Clay by Salt Wells. Norwegian Geotechnical Institute, Oslo, Norway, NGI publication no. 81.

Moum J, Løken T and Torrance JK (1971) A geochemical investigation of the sensitivity of a normally consolidated clay from Drammen, Norway. Géotechnique 21(4): 329-340, http://dx.doi.org/ 10.1680/geot.1971.21.4.329.

NGF (Norwegian Geotechnical Society) (2011) Veiledning for symboler og definisjoner i geoteknikk: Identifisering og klassifisering $i$ jord. Norwegian Geotechnical Society, Oslo, Norway, NGF-notification no. 2, 2nd revision (in Norwegian).

Penner E (1965) A study of sensitivity in Leda clay. Canadian Journal of Earth Science 2(5): 425-441.

Quigley RM (1980) Geology, mineralogy, and geochemistry of Canadian soft soils: a geotechnical perspective. Canadian Geotechnical Journal 17(2): 261-285.

Rosenqvist IT (1946) Om leirers kvikkaktighet. Norwegian Public Roads Administration, Oslo, Norway, Meddelelsen fra Vegdirektøren No. 3 (in Norwegian).

Rosenqvist IT (1953) Considerations on the sensitivity of Norwegian quick-clays. Géotechnique 3(5): 195-200, http://dx.doi.org/ 10.1680/geot.1953.3.5.195

Rosenqvist IT (1955) Investigations in the Clay-Electrolyte-Water System. Norwegian Geotechnical Institute, Oslo, Norway, NGI Publication no. 9

Rosenqvist IT (1977) A general theory for quick clay properties. Proceedings of the 3rd European Clay Conference, Oslo, Norway (Rosenqvist IT (ed.)). Nordic Society for Clay Research, Oslo, Norway, pp. 215-228.
Santamarina JC, Klein KA, Palomino A and Guimaraes MS (2002) Micro-scale aspects of chemical-mechanical coupling: interparticle forces and fabric. In Chemo-Mechanical Coupling in Clays: From Nano-Scale to Engineering Applications (Di Maio C, Hueckel T and Loret B (eds)). Swets \& Zeitlinger, Lisse, the Netherlands, pp. 47-63.

Sridharan A and Nagaraj HB (2000) Compressibility behaviour of remoulded, finegrained soils and correlation with index properties. Canadian Geotechnical Journal 37(3): 712-722.

Thakur V, Jostad HP, Kornbrekke HA and Degago SA (2014) How well do we understand the undrained strain softening response in soft sensitive clays? In Landslides in Sensitive Clays: From Geoscience to Risk Management (L'Heureux JS, Locat A, Leroueil S, Demers D and Locat J (eds)). Springer, Dordrecht, the Netherlands, pp. 291-302.

Torrance JK (1974) A laboratory investigation of the effect of leaching on the compressibility and shear strength of Norwegian marine clays. Géotechnique 24(2): 155-173, http://dx.doi.org/10.1680/geot. 1974.24.2.155.

Torrance JK (1979) Post-depositional changes in the pore water chemistry of the sensitive marine clays of the Ottawa area, eastern Canada. Engineering Geology 114(2-3): 135-147.

Torrance JK (1983) Towards a general model of quick clay development. Sedimentology 30(4): 547-555.

van Olphen H (1963) An Introduction to Clay Colloid Chemistry. Wiley, New York, NY, USA.

\section{How can you contribute?}

To discuss this paper, please email up to 500 words to the editor at journals@ice.org.uk. Your contribution will be forwarded to the author(s) for a reply and, if considered appropriate by the editorial board, it will be published as discussion in a future issue of the journal.

Proceedings journals rely entirely on contributions from the civil engineering profession (and allied disciplines). Information about how to submit your paper online is available at www.icevirtuallibrary.com/page/authors, where you will also find detailed author guidelines. 